\title{
Enfisema subcutâneo generalizado causado por ferida axilar em equino - relato de caso
}

*Autor correspondente

e-mail: ysbonacin@gmail.com

\section{Resumo}

O enfisema subcutâneo é o acúmulo de gás no espaço subcutâneo, ao longo dos feixes e das fáscias musculares. A origem do enfisema é multíplice, porém as principais são perfurações de traqueia e feridas em locais de movimento contínuo, tal como as axilas. As feridas axilares em equinos são comumente oriundas de traumas como choque mecânico com objetos inanimados, empalamento por objetos pontiagudos, além de coices proferidos por outros animais. Durante o movimento, a compressão da musculatura local realiza sucção do ar para o espaço subcutâneo, onde pode se observar crepitação e hiperalgesia. A progressão clínica do enfisema subcutâneo pode levar ao desenvolvimento de pneumomediastino, pneumotórax e infecções secundárias por bactérias do gênero clostridium. 0 objetivo deste trabalho é relatar a ocorrência do enfisema subcutâneo em um equino, bem como descrever o tratamento implementado e o resultado positivo. Um equino da raça Quarto de Milha, fêmea, com 10 anos de idade, foi referida ao Hospital Veterinário Governador Laudo Natel, da FCAV/UNESP, apresentando quadro de enfisema subcutâneo generalizado e ferida na região axilar esquerda, posterior ao olecrano. Segundo relato do proprietário, o animal apresentou desconforto durante o trabalho, constatando-se a presença de sangue e ferida perfurante, a qual evoluiu para enfisema na região da axila e, posteriormente, para o restante do corpo. Ao exame físico, o animal apresentou normalidade dos parâmetros fisiológicos e do hemograma. Na inspeção visual, possuía enfisema generalizado, estendendo-se da face até a vulva. A ferida possuía $5 \mathrm{~cm}$ de comprimento e à princípio apresentava drenagem de conteúdo serosanguinolento de odor fétido. Foi realizada limpeza da ferida com solução fisiológica e clorexidines degermante e aquoso. 0 tratamento foi realizado com limpeza diária da ferida com solução fisiológica e clorexidine aquoso, com posterior introdução de uma compressa de gaze tipo queijo, embebida em solução de nitrofurazona com açúcar. Era realizada ducha de água fria uma vez ao dia, realizando a drenagem do ar no sentido do local da ferida. Foi realizada antibioticoterapia sistêmica por 
três dias, com uso de penicilina potássica (QUID) associada ao metronidazol (BID) e à gentamicina (SID). Durante o tratamento, o animal foi mantido na baia de internação. A alta médica ocorreu em um mês de tratamento, sem nenhum sinal de enfisema ou distúrbio secundário à ocorrência do episódio. 0 caso descrito foi referido aos cuidados veterinários com quadro avançado de enfisema subcutâneo, porém complicações como pneumotórax e pneumomediastino não foram observadas. A opção pelo uso de compressa de gaze do tipo queijo, embebida em nitrofurazona e inserida na ferida, é um excelente auxílio ao tratamento de feridas provenientes de lacerações profundas. No caso descrito, a compressa de gaze impedia a entrada de uma parte de ar para o espaço subcutâneo, além de manter a solução em contato íntimo com o local, diminuindo o espaço morto. A ferida traumática não era recente, desta maneira optou-se pelo tratamento por segunda intenção. A antibioticoterapia sistêmica concomitante ao debridamento cirúrgico e limpeza criteriosa da ferida são descritas em todos os casos presentes na literatura e constituem uma estratégia importante na prevenção e tratamento de infecções bacterianas secundárias. A limitação na movimentação do animal também é importante para evitar a sucção de ar para o espaço subcutâneo. Alguns autores descrevem a drenagem do ar por uso de cateter ou incisões na pele, porém a ducha com água fria no corpo mostrou resultados satisfatórios. 0 presente trabalho conclui que o enfisema de subcutâneo, mesmo apresentado na forma generalizada, é passível de tratamento com resultados positivos, porém se faz necessário o cuidado intensivo e a detecção precoce de possíveis distúrbios secundários que possam colocar a vida do animal em risco.

Palavras-chave: Crepitação. Ferida. Axila. 